\title{
APPENDIX II. MARINE GEOPHYSICAL SURVEY (SITE 214 DSDP) ON THE NINETYEAST RIDGE, INDIAN OCEAN ${ }^{1}$
}

\author{
Bhoopal R. Naini and Stephen L. Eittreim, Lamont-Doherty Geological Observatory, \\ Columbia University, Palisades, New York
}

\begin{abstract}
A site survey of a $1^{\circ} \times 1^{\circ}$ area over the central part of the Ninetyeast Ridge indicated a linear topography with a northsouth trend. The ridge here is nearly symmetric, bell-shaped, with the western escarpment somewhat steeper than the eastern. Seismic stratigraphy revealed an upper transparent and a lower opaque layer underlain by oceanic basement. The sediment occurs as thin lenses on the crest and as linear belts along the flank. The basement topography is rough, faulted, and consists of isolated peaks. The gravity anomalies generally trend parallel to the topography. The magnetic lineations present an approximate northeastsouthwest trend. Bottom photographs show evidence of current action.
\end{abstract}

\section{INTRODUCTION}

Lamont-Doherty Geological Observatory made a detailed site survey of an approximately $1^{\circ} \times 1^{\circ}$ area over the Ninetyeast Ridge (Figures 1 and 2) during the fourteenth cruise, Leg 2 (Mauritius to Singapore, March 1971) of R/V Robert D. Conrad. The selection of this site was made on the basis of an earlier reconnaissance survey carried out by R/V Vema in September 1967. The Vema study indicated that the Ninetyeast Ridge has an almost symmetrical bell-shape, although the western escarpment is steeper than the eastern (Figure 3). The sediment consisted of transparent pelagics of about $0.1 \mathrm{sec}$ (two-way vertical reflection time, approximately 100 meters thick, assuming a velocity of $2.0 \mathrm{~km} / \mathrm{sec}$ ) thick underlain by a more prominent stratified sequence of about $0.5 \mathrm{sec}$ thickness. The objectives of the drilling were to obtain a complete biostratigraphic sequence and investigate the nature and age of the basement. This site was subsequently drilled (DSDP Leg 22, Site 214) during February 8-12, 1972 (von der Borch and Sclater et al., 1972). Site 214 is located approximately over the central part of the Ninetyeast Ridge (Figure 1). The Ninetyeast Ridge is the longest straight aseismic ridge known, extends approximately between $10^{\circ} \mathrm{N}$ and $32^{\circ} \mathrm{S}$, and runs almost along the $90^{\circ} \mathrm{E}$ meridian (Heezen and Tharp, 1965). However, it is now believed that this ridge consists of en echelon mountainous masses (Bowin, 1973) and a series of shoal regions, separated by deep channels, which may have once been coral atolls now submerged (McKenzie and Sclater, 1971).

\section{TOPOGRAPHY}

The Ninetyeast Ridge is a long linear topographic feature defined by the $4-\mathrm{km}$ isobath and the 3-km isobath with intermittent deeps. There are isolated highs shown by the 1

\footnotetext{
${ }^{1}$ Lamont-Doherty Geological Observatory Contribution No. 2005.
}

$\mathrm{km}$ isobath (Udintsev, 1963). A detailed topographic map of the survey region with bathymetric soundings in corrected meters along the ship's track, contoured at variable intervals, is given in Figure 4. It is noted that the topography defines a linear north-south local trend which is also the regional trend. There are two isolated highs of 1489 and 1677 meters, located over the central part of the area. The total topographic relief in the survey area is on the order of 2500 meters, with the western flank of the ridge much steeper than the eastern flank.

\section{GRAVITY}

A detailed free-air anomaly map of the study area contoured at 5-mgal intervals is given in Figure 5. There is a close correlation between the trend of the free-air gravity anomalies and the topography. Two isolated gravity anomaly highs of +45 and +60 mgal correlate with the crest of the ridge. The local change in the gravity anomaly from the ridge flanks to the ridge crest is about $80 \mathrm{mgal}$ (Figure $5)$. The positive free-air gravity anomalies which correlate with the ridge crest form part of a belt of positive anomalies associated with the entire length of the Ninetyeast Ridge (Talwani and Kahle, in press). The positive anomalies are bordered by belts of negative anomalies.

\section{MAGNETICS}

No pattern to the regional magnetic anomalies over the Ninetyeast Ridge has yet been discerned. In the basin west of the ridge the east-west-trending sea-floor spreading anomalies (anomalies 23-30) approximately between $2^{\circ} \mathrm{S}$ and $20^{\circ} \mathrm{S}$ have been identified (McKenzie and Sclater, 1971). No anomaly identifications have yet been published on the Wharton Basin (see, however, Chapter 41). The residual total intensity magnetic field values are plotted along the ship's track and are contoured at 50-gamma intervals (Figure 6). The total range of the anomalies is of 


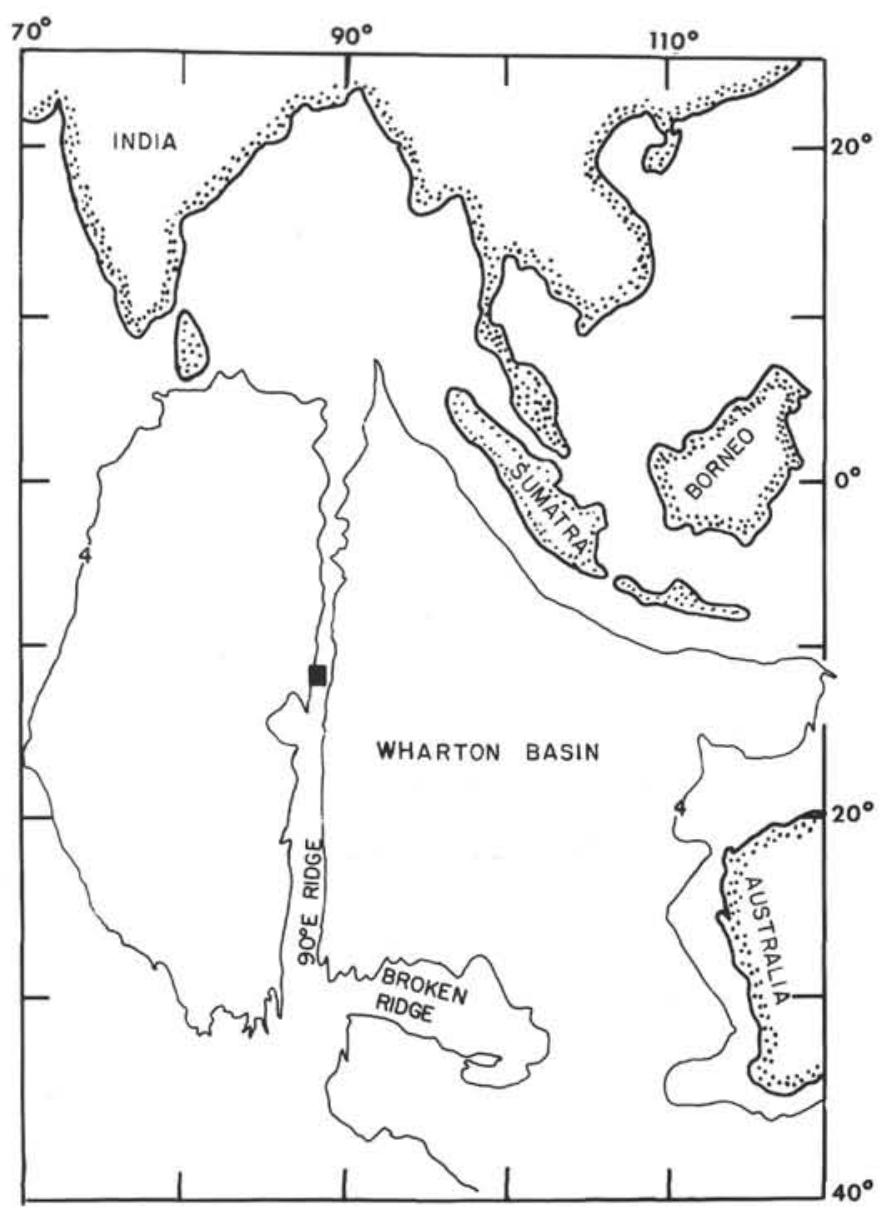

Figure 1. Indian Ocean with major topographic features outlined by 4-km isobath and location of survey area in black square.

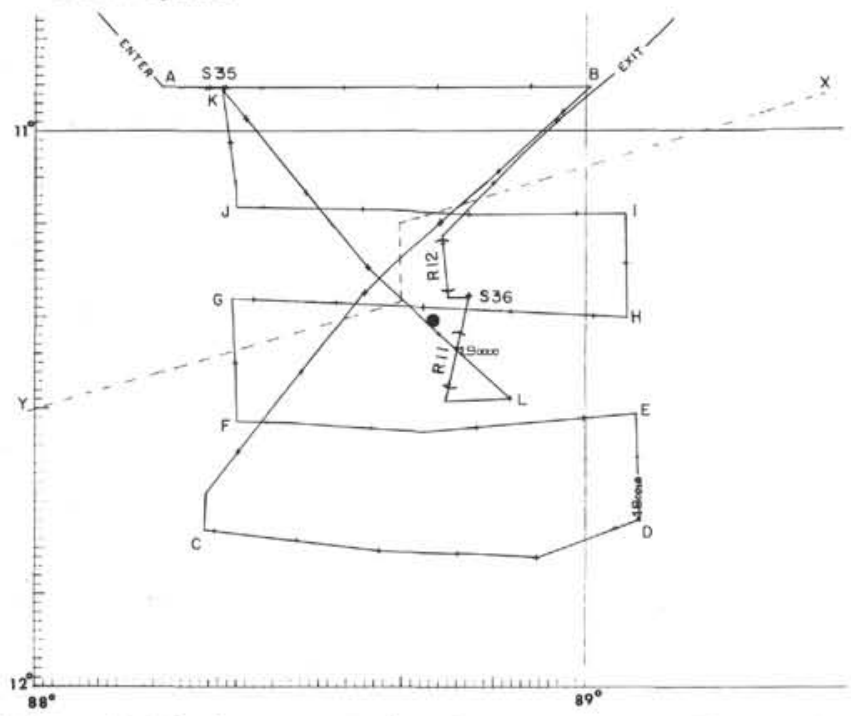

Figure 2. Track synopsis for the survey area. Plus marks correspond to time on the hour at 1-hour spacings. Satellite fixes once a day are marked with day and time. Numbers with prefix $S$ stand for ship station and $R$ for sonobuoy recording. Parentheses indicate duration of sonobuoy. $A B, C D$, etc are locations of seismic reflection profiles of Figure 7. Black circle (also in Figures 4, 5, 6, and 8) is location of Site 214.

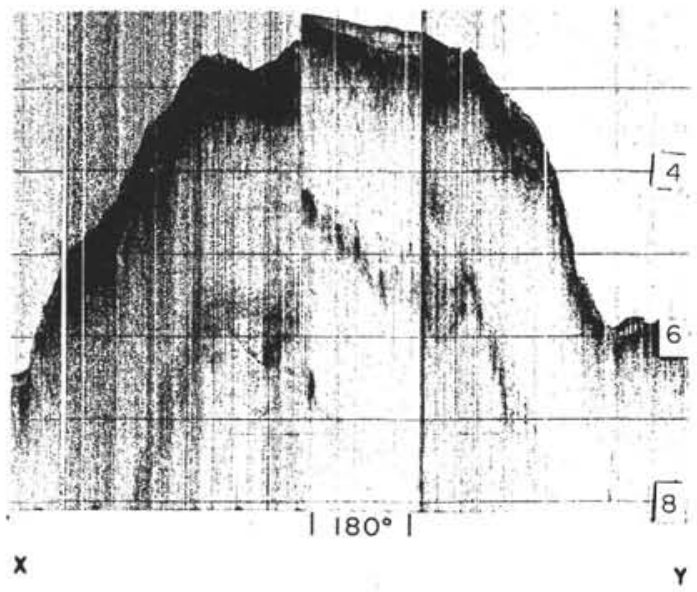

Figure 3. Vema 24 seismic reflection profile along section $X Y$ of Figure 2 showing near symmetric bell-shape of the Ninetyeast Ridge at this location.

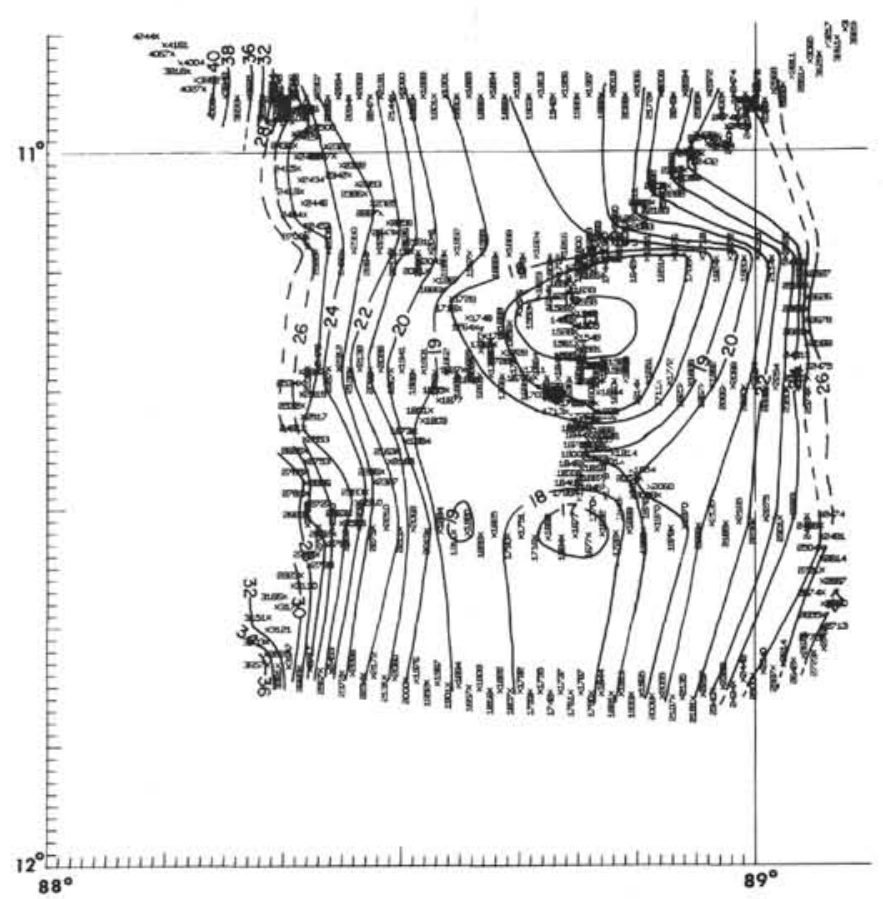

Figure 4. Bathymetric soundings in corrected meters in the survey area plotted along the ship's track contoured in hundreds of meters at variable intervals.

the order of 800 gammas. An obvious northeast-southwesttrending lineation pattern representing the alternate positive and negative bands is seen. This local magnetic trend is entirely different from that presented by the gravity and topography.

\section{SEISMIC REFLECTION AND REFRACTION}

The low-frequency airgun vertical seismic profiler records along the ship's track are shown in Figures $7 \mathrm{a}-7 \mathrm{~g}$. It can be seen that two types of sedimentary layers are present. On the top there is an acoustically transparent layer underlain by a more stratified opaque layer. The transparent layer has a thickness of about $0.1 \mathrm{sec}$ and the 


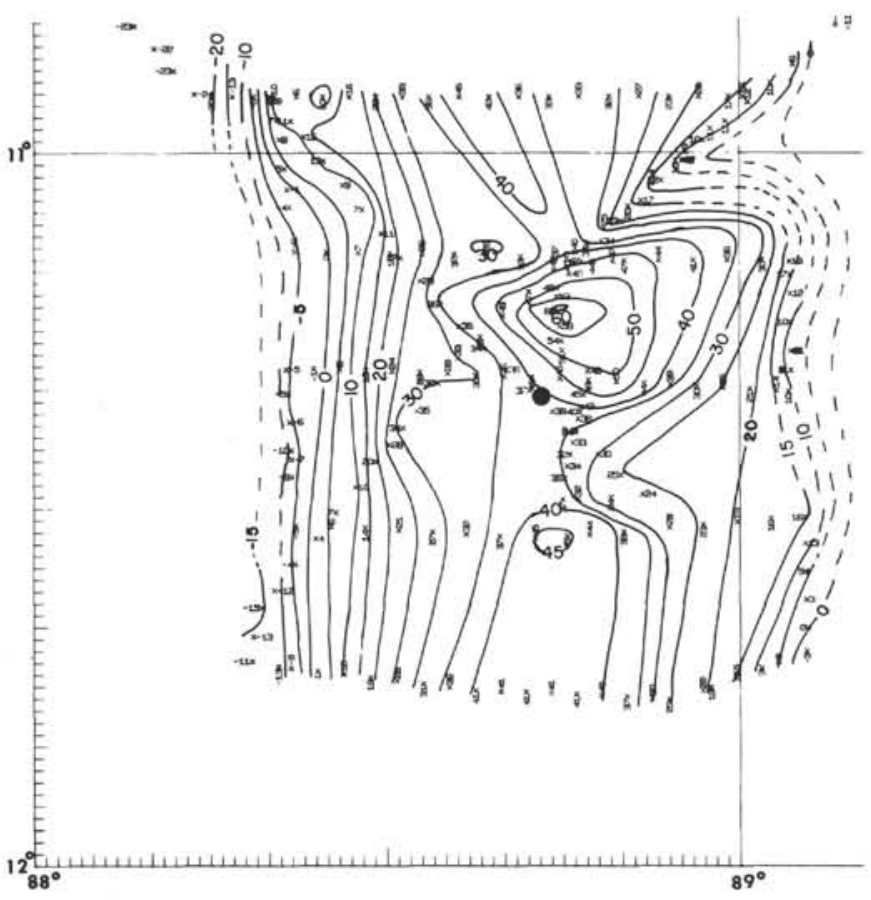

Figure 5. Free-air anomaly values in milligals plotted along ship's track and contoured at 5-mgal intervals in the survey area.

opaque layer of about $0.3 \mathrm{sec}$ on the crest of the ridge. On the flanks, however, the thickness of both of these layers increases to a combined maximum of up to $1.0 \mathrm{sec}$. The sediment is underlain by a reflector interpreted as basement (layer 2). The basement topography is very rough, faulted, and sometimes resembles horst and graben-type structures. There are isolated basement peaks. The overall local basement structure presents a near symmetrical bell-shape.

A sediment isopach map of the survey area measuring thicknesses at 10 -min intervals along the ship's track is shown in Figure 8. The total thickness ranges from 0 to 1.0 sec. Most of the sediment is found in pockets in the basement depressions, with a maximum thickness along the flanks of the ridge. The crestal region of the ridge has numerous lens-shaped sedimentary pockets. The overall sediment distribution pattern is approximately parallel to the topographic trend.

Two sonobuoys were recorded in this area (R11 and $\mathrm{R} 12)$, located at $11^{\circ} 27.6^{\prime} \mathrm{S}, 88^{\circ} 45.0^{\prime} \mathrm{E}$ and $11^{\circ} 16.9^{\prime} \mathrm{S}$, $88^{\circ} 44.8^{\prime} \mathrm{E}$, respectively (Figure 2). Wide-angle reflections yielded an interval velocity of $2.41 \mathrm{~km} / \mathrm{sec}$ for R11 for a sedimentary layer $0.4 \mathrm{~km}$ thick. No refracted arrivals were recorded. Buoy R12 yielded wide-angle reflections with an interval velocity of $1.94 \mathrm{~km} / \mathrm{sec}$ and a thickness of $0.32 \mathrm{~km}$ for the sedimentary layer. Refracted arrivals on this buoy indicated an apparent velocity of $5.38 \mathrm{~km} / \mathrm{sec}$. The interval velocities correspond to the total sedimentary column rather than to the individual layers described before. The refracted arrivals on buoy B12 correspond to the oceanic basement (layer 2) with a velocity in the Indian Ocean of $5.19 \pm 0.64 \mathrm{~km} / \mathrm{sec}$ (Shor and Raitt, 1969).

\section{BOTTOM PHOTOGRAPHS AND CORES}

Bottom photographs were taken at stations 35 and 36 (Figure 2). The sea floor at station 36 shows ripple marks (Figure 9) implying current action. A careful study of these ripples indicates that a possible current is flowing approximately from the southwest to the northeast. This current seems to be local or of variable intensity as no ripple marks were noticed at station 35 . However, the bottom here is smooth and devoid of any life forms, perhaps suggesting some current smoothing.

Two piston cores were also taken at the abovementioned stations, one on the west flank of the ridge where the deeper sedimentary layers outcrop (see Figure $7 a)$. The cores consisted of foraminiferal ooze with a high amount of coarse fraction consisting of planktonic and benthonic foraminifera, with echinoid spines and sponge spicules. The lengths of the cores were $961 \mathrm{~cm}$ at station 35 and $488 \mathrm{~cm}$ at station 36 . Foraminiferal studies have shown lower Paleocene and Pleistocene ages for these two cores, respectively (T. Saito, personal communication).

\section{CONCLUSIONS}

1) This study of the survey area revealed a linear north-south topographic trend with isolated highs in the crestal region of the ridge.

2) Locally the ridge has a near symmetrical bell-shape with the western escarpment steeper than the eastern.

3) There are two sedimentary layers (seismic stratigraphy) consisting of an upper transparent layer and a lower stratified opaque sequence underlain by the oceanic basement (layer 2).

4) The basement topography is rough, faulted, and consists of isolated peaks.

5) The free-air gravity anomaly pattern is comformable with that of the topography.

6) Well-defined magnetic lineations present an approximate northeast-southwest trend.

7) Bottom photographs indicate the presence of local current action from the southwest.

\section{ACKNOWLEDGMENTS}

We thank Mr. Olav Eldholm and Dr. Yves Lancelot for their criticism of the paper and Drs. Roger L. Larson and Anthony B. Watts for helpful comments. We are grateful to Mr. John I. Ewing for his guidance. Many thanks are due to the officers and crew of $\mathrm{R} / \mathrm{V}$ Conrad and Miss Betty Batchelder for drafting and typing help. This work was supported under grants GA27281 and GA28338 from the National Science Foundation and the Office of Naval Research contract N00014-67-A-0108-0004.

\section{REFERENCES}

Bowin, C. O., 1973. Origin of Ninetyeast Ridge from studies near the equator (Abstract): Am. Geophys. Union Trans., v. 54 , p. 330.

Heezen, B. C. and Tharp, M., 1965. Physiographic diagram of the Indian Ocean, the Red Sea, The South China Sea, the Sulu Sea and the Celebes Sea (with descriptive sheet): New York Geol. Soc., Am., Inc.

McKenzie, D. and Sclater, J. G., 1971. The evolution of the Indian Ocean since the Late Cretaceous: Geophys. J. Roy. Astro. Soc., v. 25, p. 437-528. 


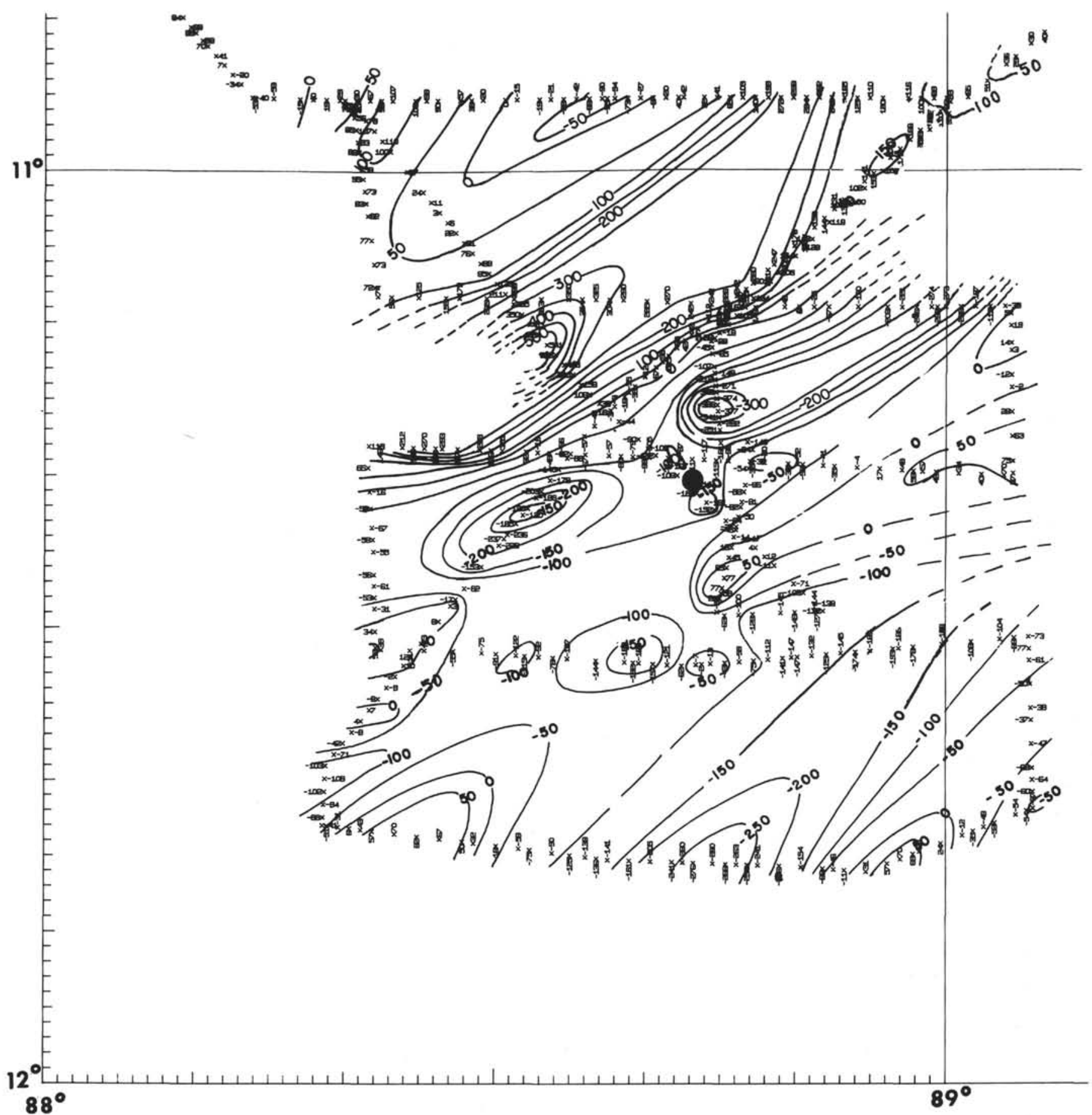

Figure 6. Total intensity residual magnetic anomaly values in the survey area plotted along ship's track and contoured at 50-gamma intervals.

Shor, G. G., Jr. and Raitt, R. W., 1969. Explosion seismic studies of the crust and upper mantle in the Pacific and Indian oceans. In The earth's crust and upper mantle, Hart, P. J. (Ed.), Geophys. Mono. 13: Washington (Am. Geophys. Union), p. 225-230.

Talwani, M. and Kahle, H. G., in press. Free-air gravity charts of the Indian Ocean. In Udintsev, G., (Ed.), The atlas of geology and geophysics of the international Indian Ocean expedition.
Udintsev, G., 1963. World bathymetric map, Indian Oceap Sheet: NRKch GUGK, Moscow.

von der Borch, C. C., Sclater, J. G., Gartner, S., Jr,, Hekinian, R., Johnson, D. A., McGowran, B., Pimm, A. C., Thompson, R. W., and Veevers, J. J., 1972. Deep Sea Drilling Project, Leg 22: Geotimes, v. 17, p. 15-17. 

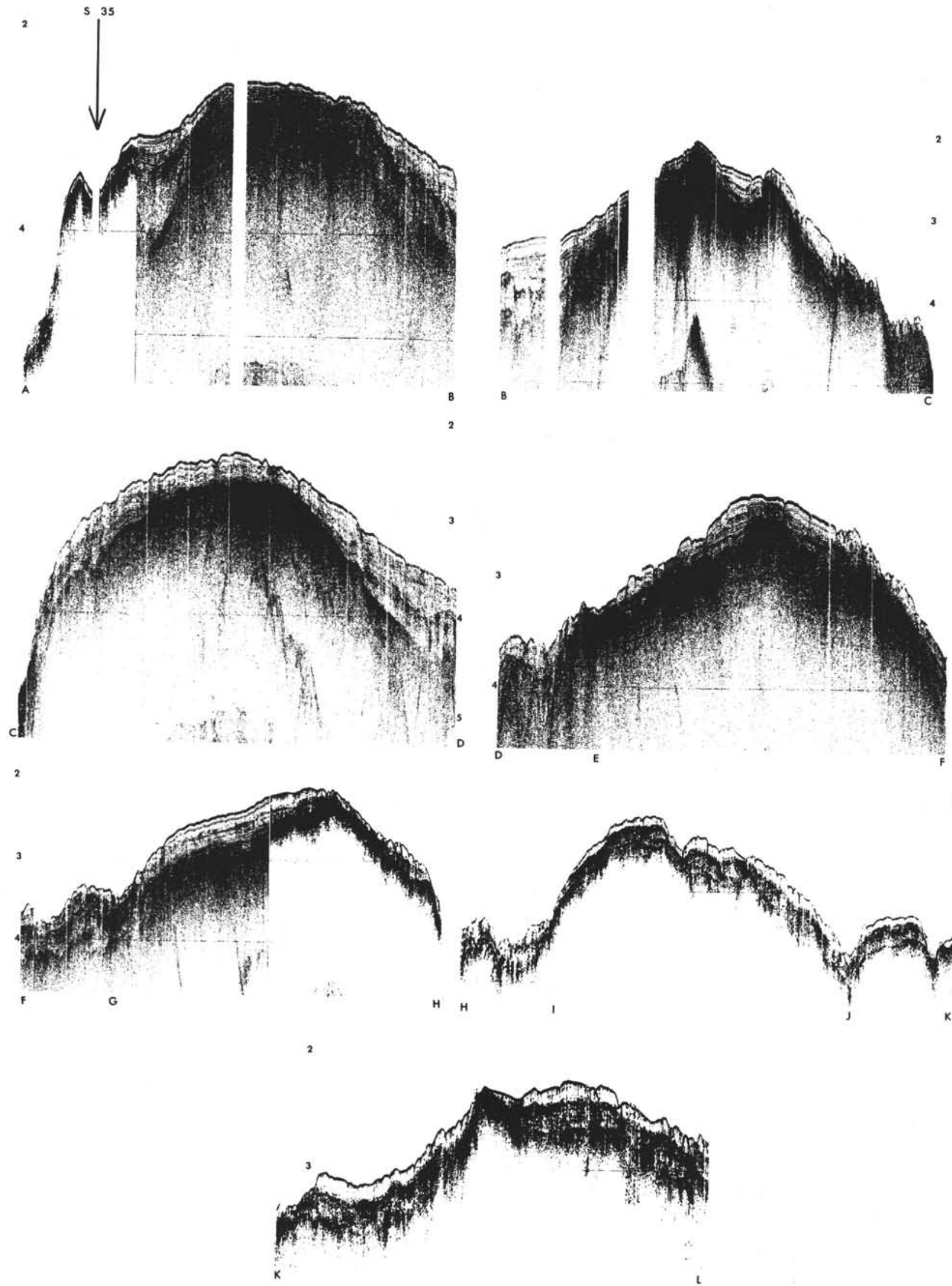

Figure 7a-g. Seismic reflection profiles over the Ninetyeast Ridge showing various features described in the text. Section locations are shown in Figure 2. Vertical scale is two-way reflection time in seconds. 


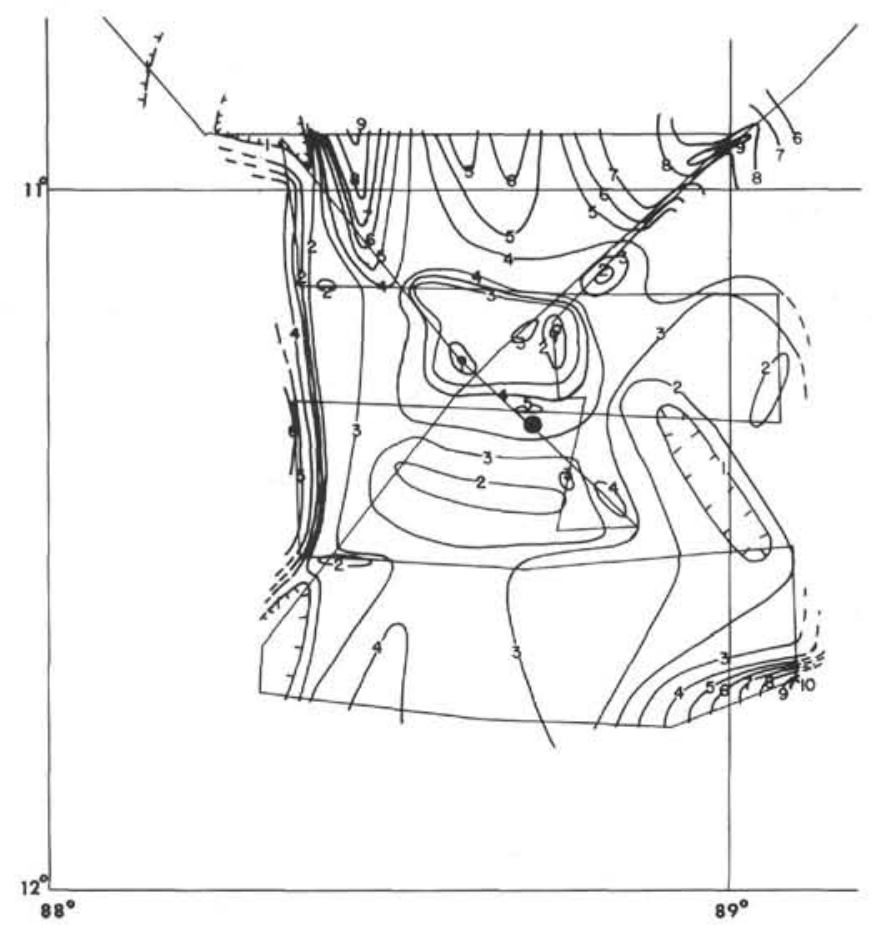

Figure 8. Sediment isopach map of the survey area based on readings of travel time through sediment at 10-min intervals and contoured in tenths of seconds two-way reflection time. Hachures are towards basement outcrop. 

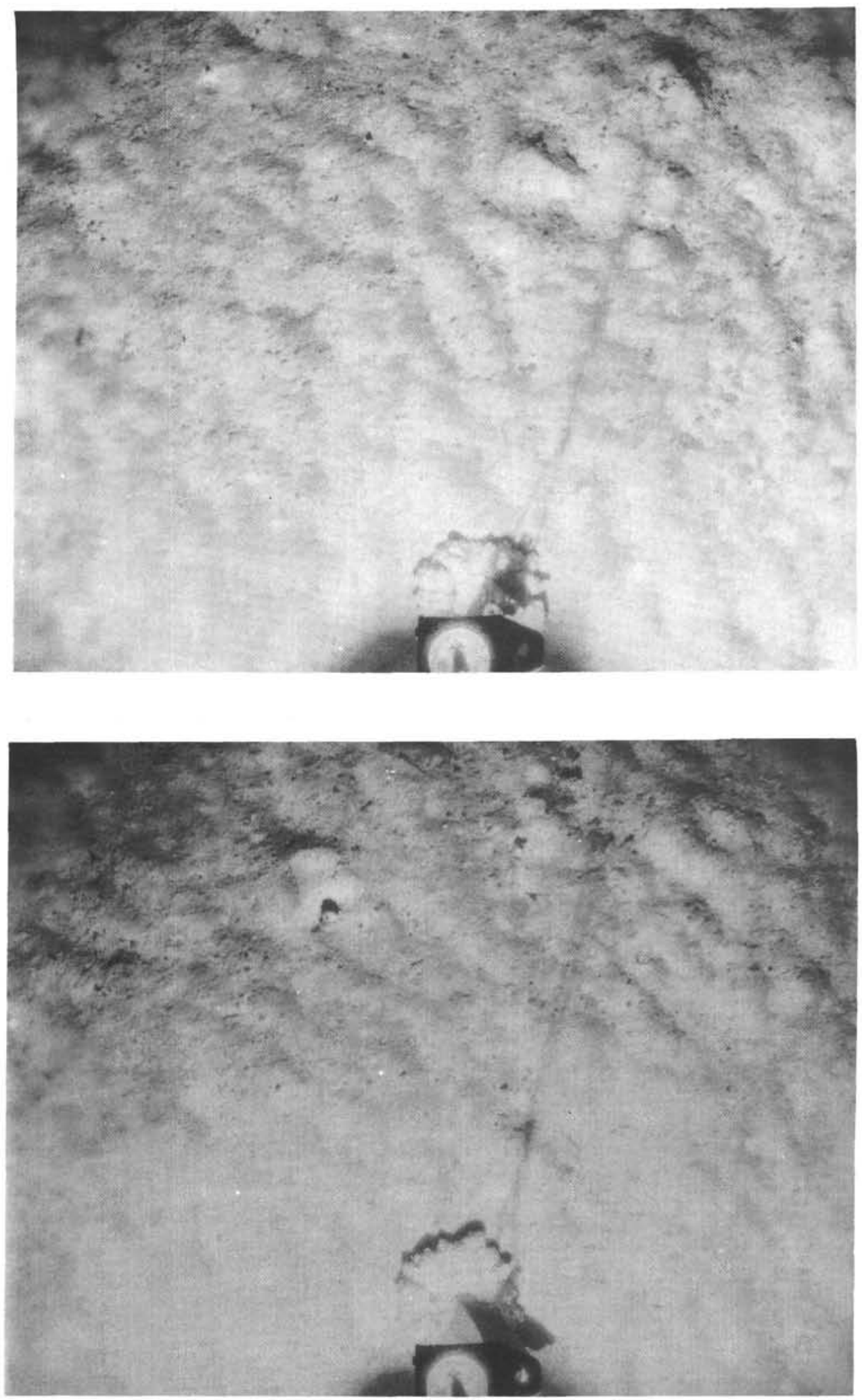

Figure 9. Photographs of the bottom taken at station 36 (see Figure 2 for location) showing ripple marks indicative of current action with a flow from southwest to northeast. Area photographed is about $2 \times 1$ meters. 